\title{
How did Ideas about Gender Influence Women's Entry into the British Medical Profession Prior to WWII?
}

\author{
Sreedhar Krishna*
}

Faculty of Medicine, Imperial College London

\begin{abstract}
The path for British women into medicine has changed beyond recognition. This short essay examines how gender role ideology has influenced women's entry into this profession, tracing the arduous journey travelled by the early pioneers and the obstacles faced. This article is particularly relevant with today's context, where women now outnumber their male counterparts in the British medical education system. The common belief that women were not explicitly discriminated against by the medical establishment is also challenged. Furthermore, the means by which male incumbents monopolised skills are discussed and the effects of war on occupational entry are outlined.
\end{abstract}

\section{INTRODUCTION}

If universalism were to characterise any individual sector, one might propose that it should be the professions. This is so, because professions, and their constituent professionals, are presumably axiomatically committed to the production, dissemination and proficient use of knowledge [1]. One might reasonably think that such a noble cause would enthuse its members and defeat functionally irrelevant factors such as ideology, prejudice and dogmatic traditionalism. Yet the professions have no more avoided discrimination arising from these factors than have working- class labour unions or the upper echelons of corporations. The professions are, in fact, contested arenas in which tumultuous power struggles determine very definite winners and losers. By means of political and economic monopolisation, the emergent victors wrest control of its institutional organisations, its theory and practice, profits and prestige. Contrasting the extreme positions on gender roles (i.e. the Parsons model), this essay will consider how gender role ideology influenced women's entry into the British medical profession prior to World War II [2].

How does a particular group attain professional status? Sociologist Elliot Freidson answers: "A profession attains and maintains its position by virtue of the protection and patronage of some elite segment of society which has been persuaded that there is some special value in its work" [3]. Thus, professions are the products of the ruling class. Hence, patronage of the ruling class was necessary to win monopoly and become the medical professional. In the early $19^{\text {th }}$ century, a professional was by definition a man. The medical profession, in contrast to the actual practice of healing, still demanded the public deference afforded by the status of "gentleman". Thus, the common assertion that professionalism did not profoundly limit women's medical status simply because licensing laws and the system of apprenticeship did

*Address correspondence to this author at the Faculty of Medicine, Imperial College London, South Kensington Campus, SW7 2AZ, United Kingdom; Tel: 0208908 3723; E-mail: sreedhar.krishna@imperial.ac.uk not knowingly bar women from practice is somewhat antipodal [4]. A woman physician was a contradiction in terms.

Historically, women have always been healers. Yet in the pre-WWII era, when allowed to participate in the healing process, it was virtually always confined to a nurse's capacity. Nurses served as merely ancillary workers, (Latin ancilla: maid servant) subservient to the dominant male doctor. Women who embraced societal norms and resided in their 'natural' domestic spheres were celebrated [5]. It was explained that women's subservience was biologically ordained: women are inherently nurse-like and not doctorlike. An editorial in the Lancet, praised women for their helpful and sympathetic nature, designating these ingredients of a good nurse. Per contra, women who dared to become doctors risked upsetting the natural harmony. The editorial warns. "The superiority asserted and the deference claimed by the woman doctor will not readily be conceded by her less favoured but not less ambitious sister [6]".

In my opinion, the strongest argument against female doctors was that derived from physiology. In 1872, von Bischoff published a well-received article arguing women lacked physical stamina, brain capacity and were too emotional. Edward Clarke, a foremost proponent of this argument, claimed that "The regimen of a college arranged for boys, if imposed on girls, would foster a whole host of debilitating diseases." Preying on the stigma associated with sterility, Clarke warned that the great physiological strain of medical education could render a woman infertile [7]. Despite an incisive retort by Davies pointing out that "working class women continued working at often physically demanding jobs all through their [menstrual] cycle", Clarke's far-reaching ideology was dominant. Fuelling the fear that education "unsexed" women, the satirical Punch magazine parodied the following "Woman of the Future".

$O$ pedants of these later days, who go on
undiscerning,

To overload a woman's brain and cram our girls with learning, 
You'll make a woman half a man, the souls of parents vexing,

\section{To find that all the gentle sex this process is unsexing}

Leave one or two nice girl before the sex your system smothers,

Or what on earth will poor men do for sweethearts, wives and mothers? [7]

Punch also poked fun at the fictional "Girton girl" [8], a stereotyped pretty attractive young woman, whom it was difficult to believe, would be interested in obtaining a university degree. Intellectual women who sought higher education were depicted as physically unattractive and characteristically unfeminine, symbolised by an unhealthy, anaemic faces and the fact that they wore glasses.

Particularly prominent in these physiological arguments was the notion of women's intellectual inferiority. Even if women ignored the injurious effects of medical education, they were perceived as simply incapable of withstanding the intellectual rigour of the course. An 1848 obstetrical text states, "She [woman] has a head too small for intellect but just big enough for love" [9]. From the mid $18^{\text {th }}$ century, doctors were actively seeking to climb social strata claiming that the 'esoteric form of knowledge' which they had appropriated could only be fully understood by the medical professional [10].

The admission that these phrenologically proven inferiors were capable of medical qualification could destroy the professional demarcation so desired by doctors. This is emblematic of labour market shelters constructed by male doctors to restrict competition, an issue that will be discussed later. This is not to suggest that these views were entirely homogeneous, as attested to by contemporary accounts referring to the "quick intelligence [and] inexhaustible energy" of Jex-Blake [7].

Exceptionally strong-minded women such as Jex-Blake and Blackwell who ignored these perceived dangers still faced numerous sexist hurdles. During the 1850s, the great variability in the quality of medical education obtained by different practitioners prompted a movement to raise standards in male educational establishments. Conforming to the social dictates of women's intellectual inferiority, women's medical school education was assumed to be distinctly worse still and was used as an argument for the exclusion of women from the medical profession. Perhaps, to counter this argument Jex-Blake embarked upon her crusade towards medical coeducation. Most faculty and administrators, cognisant of the monetary windfall women's presence brought, did not provide an impenetrable defence against coeducation. St. Mary's Hospital Medical School, for instance, enjoyed a gradual upturn in its finances owing to the admission of women and moreover, the increased charge per capita [11]. The staunchest resistance instead, was provided by the male medical students. After lengthy controversy, seven women were admitted in Edinburgh. Before long, it became adequately clear that women were competing for prizes and honours in competition with the men. Seeking to avoid further embarrassment, "some of the professors and students began to agitate" [11]. The memorable "Riot" at Surgeon's Hall is vividly recounted by Jex-
Blake: "As soon as we reached the Surgeon's Hall we saw a dense mob filling up the road... The crowd was sufficient to stop all the traffic for an hour. We walked up to the gates, which remained open until we came within a yard of them, when they were slammed in our faces by a number of young men." Incredibly, after four years of expensive education, the University of Edinburgh refused to grant the women the degrees they had earned.

A less tenacious character than Jex-Blake would have summarily accepted defeat at this stage, but she instead proceeded to graduate at the University of Dublin [12].

Women who managed to endure this arduous journey and obtain a medical degree were still oppressed. Women doctors were herded into acceptably "feminine" specialities such as public health, hygiene, gynaecology, paediatrics and obstetrics, thereby maintaining prestigious specialities as the sole preserve of man. Unwittingly, one of these cul-de-sacs into which women were coerced, served as an effective recruiter of the female doctor.

Throughout the early nineteenth century, it was widely assumed that at least rudimentary knowledge of physiology for the general public was vital, especially so for women. As such, lectures and books emphasising the association between physiology and hygiene were well-received. As lay knowledge and expectations increased, the validity of the imparted advice was not wholly accepted by its Victorian audience unless it carried a certificate of suitability, in the form of the author's medical degree. Since the well-being of the family and children was viewed as an element of the domestic sphere, and this gave credence to the argument that medically trained women were a necessity. Moreover, "the shift in the physiology paradigm" meant that male doctors had largely abandoned the practical application of physiology in the form of hygiene for the excitement of the physiology laboratory. Thus, the derelict ship of hygiene was soon colonised by this new generation of medical women [11].

Just as women were expected to reside in their domestic sphere, men too were expected to conform to an honour code designating social norms [12]. The honour codes, so prevalent in upper class British society, regulated male conflict and sociability throughout the $19^{\text {th }}$ century. A man's honour consisted of not only his capacity to control his land and material assets but also the conduct of his wife and children. One can identify a 'hierarchy of disincentives' against female doctors, deeply entrenched in the practices of a masculine honour culture. In view of the fact that a willingness and ability to engage in violence served as a warrant for the sincerity of one's statements, it is likely that in such situations women would have been frightened and silenced. Further down the hierarchy, but no less remindful of violence, was the 'unholy trinity of smoking, drinking and profanity' which were conspicuous expressions of male exclusivity. Jex-Blake, during her aforementioned 'Riot', described being locked out of her anatomy examination by male medical students "who stood within, smoking and passing about bottles of whiskey, while they abused us in the foulest possible language" [13]. Garner writes that in St. Mary's Hospital Medical School "Only here did the harddrinking, hard-living, rugby-playing, public-school educated medic achieve ubiquity, with all his attendant machismo and 
preposterous ritual" [11]. Incredibly, women were accused of diluting the school's 'institutional virility', and this was manifested by the consequent decline in the rugby team's performance [11].

World War I is often pinpointed as a watershed for women - a precipitant event that separated women from their social bondage and contemporary role. It is often stated that total war requires a total commitment [14].

From this perspective, victory demands that all of a nation's resources are channelled into the war effort, manpower as vital as ammunition. D'Ann wrote "every man, woman, and child of a nation must be involved, and large bureaucracies must plan, organize, and administer the war effort". Hence, she continues, "the nature of total war in this century necessarily involves women both directly and indirectly in the war effort" [15]. In its effort to mobilise its war machine, Britain could not neglect its domestic needs and so absorbed an erstwhile-untapped labour supply, namely women. Released from the private sphere of domesticity, women became the bus-conductors, ambulance drivers and agricultural laborers of Britain. Winston Churchill declared that "without the work of women it would have been impossible to win the war" [16]. As barriers to medical entry were lowered in response "to a problem extraneous to the needs of women - such as a war" women chose to enter medicine in large numbers [5].

Whether women were admitted thus depended more on gatekeepers than on the individual choices of women. When women were needed (e.g. wartime), gatekeepers sought them out. When, however, the supply of male labour was replete (e.g. when male doctors returned from war), gatekeepers preferred men over women.

The disaster and upheaval of war rendered Britain reminiscent. Leed points out "War experience is nothing if not a transgression of distinctions that were central to orderly thought, communicable experience, and normal relations" [17]. Perhaps in an effort to recreate the "traditional" feel of prewar society, Britons sought to reestablish sexual differences based on natural biological categories. The praise with which wartime women were showered, such as the recommendation of Churchill, soon faded behind the emergent hostility provoked by male unemployment. In the backdrop of social vilification, women doctors were rapidly marginalised and the "chummy male" monopoly reformed.

Furthermore, World War I ratified Mosley's notion of masculine men (qtd. in [18]). As Hartley eloquently communicates, "Military organisation and battle afforded the grand opportunity for the superior force capacity of the male. Again man was the fighter, the protector of woman and the home. And at once his power became a reality" (qtd. in [18]).

As the Parson's model alludes to, there was significant active role segregation. Male incumbents used a variety of mechanisms to monopolise skills; this monopoly allowed doctors to control and consequently occupational entry. The power wielded by those atop the medical hierarchy created labour-market shelters to restrict competition from women and hostile environments that inhibited their retention. Men, assured in their physiological superiority over women, did not want or feel the need to share the advantages of their sex and profession. Educated women were perceived as ineligible competitors in the quest for prestige and impeded at every stage. Worst of all, this competition was seen as an affront to their masculinity and position as patriarch and breadwinner.

Although women have clearly gained access to a medical education, there is evidence to suggest that more insidious barriers remain. Not until 1993 did Britain see its first female professor of surgery, perhaps indicating that women's success in certain specialties is still impeded [11]. Only when these more subtle forms of discrimination are vanquished full integration and a true meritocracy will be established.

\section{REFERENCES}

[1] Kasher A. Professional ethics and collective professiona autonomy: A conceptual analysis. Ethical Perspect 2005; 12: 67-97.

[2] Parsons T, Balis R. Family: Socialisation and Interaction Process London: Routledge 1998.

[3] Freidson E. Profession of Medicine: A Study of the Sociology of Applied Knowledge. Chicago: CU Press 1988; vol. 72.

[4] Walsh M. Doctors wanted - No Women Need Apply: Sexual Barriers in the Medical Profession, 1835-1975. New Haven: Yale University Press 1979

[5] Anderson B, Zinsser J. A History of their Own: Women in Europe from Prehistory to the Present, London: Penguin 1989; pp. 24-52.

[6] Editorial. Lancet 1873; 2: 159-60.

[7] Bonner T. To the Ends of the Earth: Women's Search for Education in Medicine (1992). London: Harvard University Press 1992.

[8] Allen G. The Woman Who Did. London: Kessinger Publishing Company 2004.

[9] Prins Y. Lady's Greek (With the Accents): A Metrical Translation of Euripides. Vic Lit Cult 2006; 34: 591-618.

[10] Burnap G. The Sphere and Duties of Woman: A Course of Lectures London: George Quigley 1848: pp. 307-310.

[11] Garner J. The Great Experiment: The Admission of Women Students to St.Mary's Hospital Medical School, 1916-1925. Med Hist 1998; 42(1): 68-88.

[12] Thomson E. Physiology, Hygiene and the Entry of Women to the Medical Profession in Edinburgh c. 1869-c. 1900. Study of History, Philosophy. Biol Biomed Sci 2001; 32(1): 105-26.

[13] Jex-Blake S. (qtd. in Witz A. Professions and Patriarchy. London: Routledge 1992; p. 90.

[14] Shaw M. Dialectics of War: An Essay in the Social Theory of Total War and Peace. London: Pluto Press 1988.

[15] Poulos P. A Woman's War too: U.S. Women in the Military in world war II. Michigan: Diane Publishing Company 1996.

[16] Morrow J. The Great War: An Imperial History. London: Routledge 2003; p. 224.

[17] Leed EJ. No Man's Land. Combat and Identity in World War I. Cambridge: Cambridge University Press 1981; p. 21.

[18] Kent S. The Politics of Sexual Difference: World War I and the Demise of British Feminism. J Br Stud 1988; 27: 232-53. 